\title{
Ekek anti mikroba terapi larva
}

\author{
Sunny Wangko \\ Bagian Anatomi-Histologi Fakultas Kedokteran \\ Universitas Sam Ratulangi Manado \\ Email: sunnywangko@yahoo.com
}

\begin{abstract}
Chronic wound is still a world-wide problem that spends a very high cost related to its management and treatment. Although there are a lot of promising studies about wound healing process, the prevalence and incidence of chronic wound and its complications are still high. Conventionally, the management of chronic wound consists of surgical debridement, manual irrigation, dressing, and antimicrobial therapy (topical and/or systemic). It is accepted that microbial biofilm and its complexity play important roles in non-healing wounds. This biofilm consists of polymicrobial colonies embedded in exopolymeric matrix produced by the biofilm itself and has a high tolerance to host defence mechanisme, antibiotics, and antiseptics. Larval therapy has been approved by FDA to be used in chronic wound management. It has antimicrobial effects besides its other effects on wound healing inter alia mechanical debridement, anti-inflammation, angiogenesis, and destabilization of biofilm enzymes. Further studies are needed to explore the effects of larval therapy, especially its excretion/secretion components, so that it can be applicated more aesthetically.
\end{abstract}

Keywords: chronic wound, wound healing process, biofilm, larval therapy

\begin{abstract}
Abstrak: Luka kronis merupakan masalah kesehatan di seluruh dunia yang telah memboroskan biaya cukup tinggi. Walaupun telah terjadi kemajuan dan pemahaman mengenai penyembuhan luka, prevalensi dan insidensi luka kronis dan komplikasinya tetap meningkat pesat. Secara konvensional, perawatan luka kronis terdiri dari debrideman, irigasi manual, dressing untuk mempertahankan kelembaban, dan terapi antimikroba (topikal dan atau sistemik). Adanya biofilm mikroba serta kompleksitasnya pada luka kronis telah disepakati sebagai salah satu kunci gagalnya penyembuhan luka. Biofilm mikroba terdiri dari koloni-koloni mikroorganisme polimikrobial terkemas dalam matriks eksopolimerik yang diproduksi olehnya sendiri dan memiliki toleransi tinggi terhadap pertahanan pejamu (host), antibiotik, dan antiseptik. Terapi larva telah diterima oleh FDA dan telah terbukti berefek antimikroba disamping efek lainnya terhadap penyembuhan luka, antara lain: debrideman mekanis, anti-inflamasi, angiogenesis, dan destabilisasi enzim biofilm pada luka. Studi lanjut diperlukan untuk mengeksplorasi efek terapi larva terutama komponen ekskresi/skresi larva terhadap penyembuhan luka agar dapat diaplikasikan secara lebih estetik.
\end{abstract}

Kata kunci: luka kronis, penyembuhan luka, biofilm, terapi larva

Luka kronis termasuk ulkus diabetik, ulkus akibat tekanan, dan ulkus vena kaki masih merupakan masalah kesehatan di seluruh dunia yang memboroskan biaya cukup tinggi. ${ }^{1,2}$ Di Amerika Serikat, biaya perawatan luka kronis melebihi 20 bilyun per tahun. Perawatan luka kronis terdiri dari debrideman bedah, irigasi manual, dressing yang mempertahankan kelembaban, dan terapi antimikroba topikal dan atau sistemik. Walaupun telah terjadi kemajuan dan pemahaman mengenai penyembuhan luka, prevalensi dan insidensi luka kronis dan komplikasinya tetap meningkat pesat. ${ }^{1}$ Adanya biofilm serta kompleksitasnya pada luka kronis 
telah dikenal sangat berperan dalam kegagalan penyembuhan luka. ${ }^{1-4}$

Biofilm bakteri ialah koloni-koloni organisme polimikrobial (bakteria, fungus, dll) terkemas dalam matriks eksopolimerik yang diproduksi olehnya sendiri dan memiliki toleransi tinggi terhadap pertahanan pejamu (host), antibiotik dan antiseptik. $^{3-6}$ Diperkirakan terdapat ratarata 6,3 spesies bakteri pada luka kronis yang didominasi oleh Pseudomonas aeruginosa dan Staphylococcus aureus. ${ }^{5}$ Oleh karena itu diperlukan terapi alternatif yang dapat menekan pembentukan biofilm pada luka kronis. Eradikasi bakteri pembentuk biofilm sangat sulit dilakukan sehingga pilihan terbaik ialah mengangkat daerah yang terinfeksi bila memungkinkan (dirupsi biofilm) disertai pemberian anti mikroba. Terdapat beberapa cara untuk melakukan disrupsi biofilm yaitu antara lain: gelombang ultrasound, negative pressure therapy, dan terapi larva. ${ }^{6,7}$ Selain sebagai antimikroba dan disrupsi biofilm, terapi larva telah diketahui memiliki berbagai efek lainnya yang menguntungkan terhadap penyembuhan luka kronis, yaitu antara lain terhadap: respons inflamasi, sistem komplemen, fibrinolisis, dan angiogenesis (Gambar 1). ${ }^{1,6,7}$ Walaupun studi mengenai efek ekskreta/sekret (E/S) larva telah cukup banyak dilakukan, belum banyak studi yang melaporkan mengenai komponen yang berefek antimikroba dan anti biofilm E/S secara in vivo. ${ }^{5}$ Studi lanjut diharapkan dapat mengeksplorasi bahan antimikroba dalam komponen E/S serta kepekaan bakteri terhadap bahan tersebut secara in vivo.

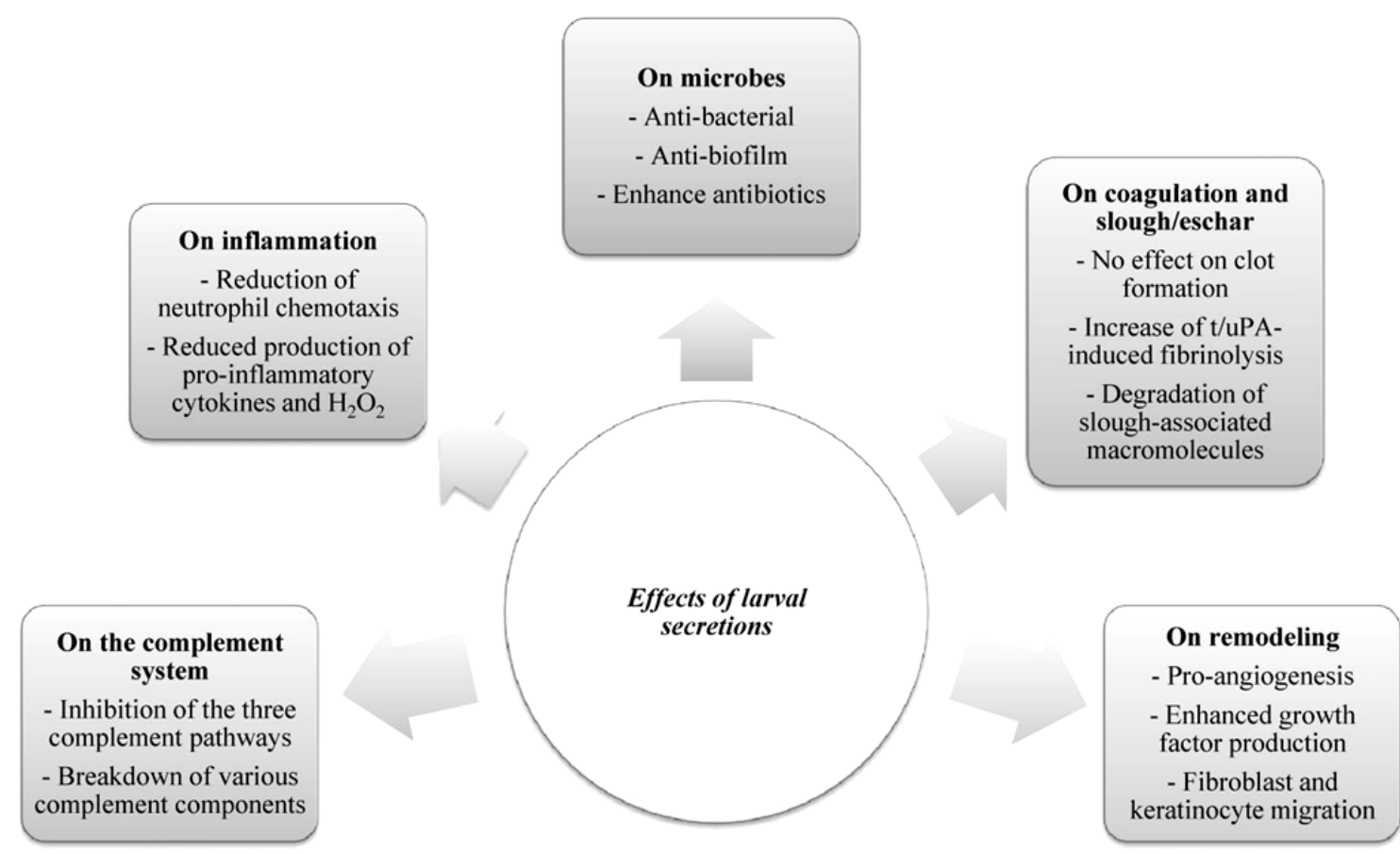

Removal of non-viable tissue/debridement

Promotion of wound bed preparation and wound healing

Gambar 1. Gambar ikhtisar kerja sekresi larva pada luka. Sumber: Cazander G et al, 2013. ${ }^{7}$ 
Luka kronis

\section{Masalah penyembuhan luka}

Penyembuhan luka merupakan proses yang sangat dinamis dan melibatkan berbagai interaksi antar molekul matriks ekstrasel, mediator, sel-sel jaringan termasuk pembuluh darah, dan infiltrasi leukosit. ${ }^{8}$ Proses penyembuhan luka terdiri dari beberapa fase yang saling berintegrasi dan tumpang tindih, yaitu: hemostasis; inflamasi; diferensiasi sel mesenkim, proliferasi, dan migrasi ke area luka; angiogenesis yang memadai; serta reepitelisasi yang segera di atas permukaan luka. Setiap fase harus berlangsung secara tepat dan terprogram. Adanya hambatan, penyimpangan, atau perpanjangan akan mengarah ke penyembuhan luka yang terlambat atau luka kronis yang tidak menyembuh. ${ }^{9}$

Luka berpeluang infeksi bila akibat kehilangan intergritas kulit tersedia daerah lembab, hangat, dan kaya nutrien yang sangat menguntungkan pertumbuhan bakteri. Luka kronis ialah luka yang gagal menyembuh sesuai dengan waktu yang diharapkan dan menetap walaupun dengan pemberian terapi antibiotik, serta adanya respons imun dan respons inflamasi dari pejamu. ${ }^{2,6}$ Secara konvensional, perawatan luka kronis terdiri dari debrideman bedah, irigasi manual, dressing yang mempertahankan kelembaban, dan terapi antimikroba topikal dan atau sistemik. Adanya biofilm serta kompleksitasnya pada luka kronis telah disepakati sebagai salah satu kunci gagalnya penyembuhan luka. ${ }^{1,3,5,6}$ Pola biofilm telah dilaporkan pada sekitar $80 \%$ inflamasi kronis bakteri dan penyakit infeksi. ${ }^{10}$ Wolcott et al. ${ }^{11}$ melaporkan bahwa perawatan luka intensif terhadap biofilm meningkatkan frekuensi penyembuhan luka.

\section{Biofilm mikrobial}

Konsep biofilm telah muncul dalam penanganan klinis selama dekade terakhir ini. Biofilm mikrobial ialah koloni-koloni yang sesil dari organisme polimikrobial (bakteria, fungus, yeast, dan mungkin virus) yang sering simbiotik dan terus berubah; kesemuanya terkemas dalam matriks eksopolimerik (extracellular polymeric substance, exopolysachharidaes, EPS) yang disintesis olehnya sendiri, dan menghasilkan toleransi tinggi terhadap pertahanan pejamu, antibiotik, dan antiseptik dengan heterogenitas spasial dan fungsional. ${ }^{1,5,6,10}$

Matriks biofilm terdiri dari makromolekul seperti protein, DNA ekstrasel, dan polisakarida. Gabungan berbagai jenis molekul dalam matriks sekitar bakteria dalam biofilm membentuk penyekat fisik (tebal sampai beberapa ratus $\mu \mathrm{m})$ yang dapat mereduksi penetrasi dan mengikat antibiotik yang masuk (resisten terhadap antibiotik topikal dan sistemik), ${ }^{6}$ melindungi koloni-koloni dari pertahanan sel-sel inflamasi pejamu, ${ }^{10}$ serta mempunyai quorum sensing yang memfasilitasi pertumbuhan biofilm baru yang resisten. Matriks biofilm bersifat dinamik dan produksi komponennya dipicu oleh lingkungan pejamu pada alas luka (misalnya pemakaian antibiotik topikal). 1,3,6,10

Struktur biofilm terdiri dari saluransaluran yang memungkinkan sirkulasi nutrien. Sel-sel pada berbagai bagian biofilm memperlihatkan pola ekspresi gen yang berbeda, dan kompleksitas struktur biofilm dan metabolisme dapat dianalogikan sebagai jaringan dari organisme yang lebih tinggi. Sel-sel bakteri sesil melepaskan antigen dan menstimulai pembentukan antibodi pejamu tetapi tidak efektif untuk mematikan bakteri tersebut dan malahan dapat menyebabkan kerusakan kompleks imun di jaringan sekitarnya, bahkan pada individu dengan reaksi imun humoral dan selular yang baik. $^{3} \quad$ Struktur multisel biofilm memungkinkan bakteri untuk menjadi dorman dan berhibernasi agar dapat bertahan hidup dan menyebarkan genomnya. ${ }^{6,10}$ Terapi antibiotik dapat menekan gejala akibat bakteri planktonik tetapi tidak mematikan bakteri di dalam biofilm. Bakteri planktonik terlepas dari biofilm secara terprogram dan dapat menyebabkan infeksi baru sehingga biofilm menjadi 
tempat perindukan infeksi akut. ${ }^{3}$ Berbagai studi in vitro terhadap toleransi antibotik dari biofilm memperlihatkan bahwa biofilm dapat bertahan dengan pemberian dosis antibiotik yang sangat tinggi sampai 1.000 kali minimal inhibitory concentration (MIC). ${ }^{6}$

Saat bakteri mulai membentuk biofilm, melalui mekanisme molekularnya akan menarik bakteri lain untuk membentuk sistem polimikrobial yang dapat bertahan hidup. Biofilm yang bertahan lama sering dihubungkan dengan diversitas genetik dari biofilm tersebut, yang mengakibatkan terjadi luka kronis yang resisten terhadap pengobatan. Survival biofilm bakteri memerlukan ekspresi gen untuk menjamin perlekatan ke pejamu, tumbuh kembangnya sel pejamu untuk mencegah terlepasnya biofilm, menyebabkan inflamasi lokal, dan stimulasi produksi plasma pada alas luka untuk memasok nutrisi ke koloni biofilm. ${ }^{1}$

Biofilm mikrobial memicu respons inflamasi kronis dan kerusakan jaringan dimana terjadi akumulasi leukosit polimorfonuklear (PMN) dan makrofag disekitarnya. $^{1,6}$ Kedua jenis sel ini menyintesis reactive oxygen species (ROS) dalam kadar tinggi yang memengaruhi biofilm serta jaringan sekitarnya. Sel-sel inflamasi ini juga menghasilkan kadar tinggi protease (matrix metalloproteinase dan elastase) yang membantu memecahkan perlekatan antara biofilm dan jaringan yang terkena. Walaupun demikian, adanya ROS dan protease juga dapat merusak jaringan normal di sekitar luka, protein, sel-sel imun, dan sel-sel jaringan lainnya, yang berakibat tertundanya penyembuhan luka. Berbagai kondisi yang menggangu sistem imun atau menurunkan efektivitas antibiotik memungkinkan perkembangan dan penyebaran biofilm pada luka. Kondisi tersebut termasuk iskemia atau adanya jaringan nekrotik, kekurangan nutrisi, serta komorbiditas yang menggangu fungsi sistem imun tubuh, seperti HIV, diabetes, trauma fisik mayor, terapi radiasi, atau penggunaan immune-supressing drugs. ${ }^{1}$

Toleransi biofilm terhadap respons imun pejamu juga merupakan karakteristik infeksi kronis. Dalam keadaan normal, leukosit PMN merupakan sel-sel yang pertama kalli muncul di tempat infeksi dengan fungsi fagositosis mikroba dan bahan asing. Selain pada infeksi akut, leukosit PMN juga ditemukan pada infeksi kronis di sekitar biofilm. Penelitian pada biofilm Pseudomonas aeruginosa memperlihatkan bahwa leukosit PMN menjadi lumpuh atau lisis oleh faktor virulensi yang diproduksi oleh $P$. aeruginosa yang disebut rhamnolipids. Lisis leukosit PMN menyebabkan terjadinya inflamasi lanjut serta menarik leukosit PMN lainnya, dan siklus ini berkontribusi dalam terjadinya infeksi kronis. $^{6}$

Sehubungan dengan kultur bakteri yang merupakan baku emas, ternyata banyak bakteri patogen bahkan yang anerob sangat sulit dikultur. ${ }^{6}$ Selain itu, berbagai jenis bakteri dan mikroba lainnya dalam biofilm dapat menjadi toleran 20-48 jam setelah inokulasi, dan akan terus mengembangkan toleransinya. ${ }^{12}$

\section{Kelompok bakteri pada luka kronis}

Luka kronis menampung berbagai jenis komunitas bakteri yang memberikan lingkungan bervariasi bagi larva yang akan senantiasa berubah secara konsisten dan berulang. Secara umum bakteri pada luka kronis dapat dibagi atas dua kelompok, yaitu: ${ }^{13}$

1. Kelompok bakteri yang sangat peka yang menghilang secara sempurna atau komunitasnya sangat menurun setelah terapi larva. Dalam kelompok ini termasuk: E. coli, $P$. aeruginosa, dan $S$. aureus. Juga yang cukup terpengaruh oleh terapi larva ialah: $B$. fragilis, C. freundii, C. koseri, $K$. oxytoca, dan Klebsiella spp.

2. Kelompok bakteri yang tidak terpengaruh atau malahan bertambah setelah terapi larva. Kelompok ini terutama terdiri dari bakteri Gram negatif, serta sebagian Gram positif. Hal ini mungkin disebabkan oleh adaptasi bakteri atau simbiosis sebagai anggota flora usus larva. Adanya 
digesti ekstrakorpora larva memungkinkan larva telah berkontak dengan bakteri di lingkungannya yang membantu digesti tersebut. Sebagai contoh kelompok kedua ini ialah Proteus spp.

\section{Terapi larva}

Pemanfaatan larva telah digunakan untuk aplikasi medik pada luka kronis terinfeksi sejak berabad-abad lalu oleh suku Maya Indian di Amerika Tengah, aborigin Australia, dan di Cina. ${ }^{1,7,14-16}$ Pada Perang Dunia I Baer seorang ahli bedah ortopedik dari John Hopkins Hospital di Baltimore menggunakan terapi larva untuk pengobatan osteomielitis dan luka gangren gas. ${ }^{1,17-20}$ Sejak tahun 1700 -an, para ahli bedah telah mencatat bahwa larva dari jenis blow fly atau green bottle tertentu (Phaenicia sericata dan Lucilia sericata) hanya mengeluarkan jaringan nekrotik, dan memperbaiki alas luka sehingga luka lebih cepat menyembuh. Dengan ditemukannya penisilin oleh Flemming (1929) dilanjutkan oleh Florey (1939) maka penggunaan terapi larva ditinggalkan. Akibat adanya resistensi antibiotik dan meningkatnya masalah luka kronis di seluruh dunia maka terapi larva mulai diperkenalkan kembali dan telah disetujui oleh FDA untuk penggunaan larva yang diproduksi secara aseptik. ${ }^{14}$

Berbagai keuntungan terapi larva telah dikemukakan dan yang terutama ialah: debrideman yaitu mengeluarkan jaringan nekrotik; degradasi enzimatik jaringan nekrotik; efek antimikroba dari E/S larva; dan stimulasi pembentukan jaringan granulasi (Gambar 1). ${ }^{1,7,13}$

\section{Debrideman mekanis}

Siklus hidup larva blowfly sekitar 1014 hari sejak menetas sampai menjadi lalat dewasa. Larva medik diproduksi dalam keadaan steril dan karena dipertahankan dalam keadaan lembab maka larva tersebut tidak mengalami pupasi. Larva ini juga tidak akan menyusup ke dalam luka dan merusak jaringan sehat karena larva hanya mendegradasi, mencairkan, dan mengingesti jaringan nekrotik. ${ }^{1}$ Berbagai enzim protelitik telah diisolasi dari E/S larva yang dapat mencairkan laminin dan fibronektin dari matriks ekstrasel jaringan nekrotik melalui debrideman mekanis dan digesti proteolitik selama 3-5 hari aplikasi. ${ }^{15,16}$ Selain itu, larva secara cepat mengeliminasi mikroorganisme yang masuk melalui saluran cernanya, dan menstimulasi jaringan granulasi luka serta memperbaikinya sehingga mempercepat penyembuhan luka. ${ }^{15}$ Larva menyekresi (melalui kelenjar saliva) dan mengekskresi (melalui feses) ke dalam luka berbagai bahan termasuk senyawa antibiotik, dan mengadakan alkalisasi lingkungan luka. ${ }^{1,5,15,16}$ Proses makan larva melalui digesti ekstrakorpora yaitu dengan mengekskresikan kompleks campuran berbagai enzim dalam E/S-nya terutama protease yang menyerupai tripsin dan kimotropsin, dan selanjutnya menelan matriks yang telah mencair. ${ }^{5,16}$

Terapi larva dapat menekan baik pembentukan maupun biofilm yang telah terbentuk. ${ }^{1}$ Adanya gerakan-gerakan larva (crawling and wandering) pada luka juga memengaruhi survival bakteri terutama bakteri anerob yang dapat membentuk biofilm serta kurang resisten bila melalui saluran cerna larva. ${ }^{13}$ Larva juga menyekresi DNAse yang mendegradasi DNA dalam matriks eksopolimerik sehingga dapat melemahkan struktur biofilm. ${ }^{6}$

\section{Efek antimikroba}

Seranggga mempunyai sistem imun untuk mempertahankan dirinya terhadap infeksi yang diaktivasi secara fisik, dan juga melalui ingesti oral dari patogen. Imunitas ini tergantung pada deteksi dan pengenalan komponen mikroba umumnya seperti lipopolisakarida atau peptidaglikan agar dapat menghasilkan respons imun sistemik. Lectin dan peptidoglycanrecognition proteins (PGRPs) merupakan mediator penting dalam imunitas serangga yang berfungsi antara lain deteksi dan netralisasi bahan patogen dan non-self; bahan-bahan ini telah ditemukan pada berbagai jenis serangga. C-type lectin 
CLEM-36 secara spesifik diekspresikan pada ujung alat mulut pada Sarcophaga peregrina dewasa. Lalat terpapar invasi dan kolonisasi bakteri patogen pada alat mulutnya dan crop (organ penyimpan makanan) selama proses makan sehingga adanya PGRPs merupakan mekanisme pertahanan yang sempurna untuk menghindari kolonisasi pada serangga dewasa dan larva, terlebih lagi L. sericata dan serangga nekrofagus lainnya dengan habitat pada dekomposisi bangkai atau saat terapi larva. Andersen telah mengidentifikasi PGRP baru (ZY200234) dan lectin $\alpha$-subunit homologue pada kelenjar saliva dan crop L. sericata. ${ }^{14}$

Serangga mempunyai kapasitas resistensi yang besar terhadap infeksi bakteri sehingga dapat beradaptasi pada berbagai kondisi lingkungan yang umumnya dengan sanitasi buruk. Serangga berespon terhadap bakteri atau cedera dengan menyintesis peptida antimikroba (antimicrobial peptides, AMPs) secara cepat yang mempunyai spektrum luas terhadap bakteri baik Gram positif maupun negatif, serta jamur. Lebih dari 2.000 jenis AMPs telah terdaftar dan peptida yang diisolasi dari seranggalah yang terbanyak. ${ }^{15}$

Pada serangga, AMPs disintesis oleh jaringan lemak tubuh (setara dengan hati mamalia), sel epitel, dan pada sel-sel tertentu dari hemolimf (setara dengan darah mamalia) yang kemudian disebarkan ke seluruh tubuh melalui hemolimf ke lokasi infeksi. Terdapatnya residu asam amino dengan muatan positif (Arg, Lys) pada molekulnya memungkinkan AMPs untuk berinteraksi dengan fosfolipid anionik dari membran bakteri, diikuti oleh integrasi peptida ke dalam lapisan fosfolipid tersebut, kebocoran sitoplasma, dan selanjutnya kematian sel. Beberapa studi melaporkan bahwa proses mematikan bakteri ini bukan saja melalui kerusakan membran bakteri tetapi terutama melalui gangguan metabolime bakteri. Berbeda halnya dengan antibiotik konvensional, AMPs tampaknya tidak menginduksi resistensi bakteri dan bahkan hanya memerlukan waktu singkat untuk memati- kan bakteri. ${ }^{15}$ Komponen E/S tersebut dapat berdifusi ke dalam matriks biofilm. ${ }^{5}$

Dengan menggunakan expressed sequence tag (EST) project, Andersen mendapatkan septic-inducible gen $L$. Sericata dan beberapa jenis peptida dan protein yang terlibat imunitas yaitu sapecin- $\beta \quad$ homologue, diptericin homologue, tiga jenis baru AMPs yang kaya prolin, serin protease, transferin, feritin, dan lisosim serangga. Selain itu, pada $L$. sericata dewasa juga ditemukan peptida lucifensin di tubuh (full body), E/S, saluran cerna, kelenjar saliva, badan lemak, dan hemolimf yang berfek terhadap Micrococus luteus. Lisosim 1 homolog fulllength dan parsial yang diperoleh dari kelenjar saliva dan crop menunjukkan bahwa lisosim dapat dijumpai pada sekret larva dan turut berperan sebagai antimikroba pada terapi larva. ${ }^{14}$

Preskursor AMPs besar yang termasuk famili attacin dengan homologi terhadap sarcotoxin IIA diidentifikasi dari tubuh larva dan dilaporkan dapat menghambat sintesis dinding sel dan pembentukan septum Escheerichia coli. Umumnya, attacin aktif terhadap bakteri Gram negatif. Selain itu terdapat peptida lucifensin yang spesifik terhadap mikroba Gram positif $S$. carnosus, $S$. pneumoniae dan $S$. pyogenes.Terapi larva dilaporkan berefek eradikasi terhadap methicillin-resistant $S$. aureus (MRSA) dan glycopeptideintermediate $S$. aureus (GISA) seperti defensin lainnya. ${ }^{14}$

Defensin merupakan peptida antimikroba pada E/S serangga yang dapat mematikan terutama kuman Gram positif dan jenis jamur tertentu sedangkan kuman Gram negatif lebih resisten terhadap defensin. Dua senyawa terpenting yang telah diidentifikasi pada defensin dari larva medis Lucilia sericata dan Lucilia cuprina yaitu lucifensin I dan II secara berurutan. ${ }^{15}$ Cerovsky ${ }^{15}$ melaporkan bahwa terapi larva L. sericata secara cepat mengeliminasi kuman Gram positif dan beberapa jenis Gram negatif pada pasien ulkus diabetik yang terinfeksi, tetapi tidak efektif terhadap Pseudomonas sp. dan Acinobacter sp. 
Barnes et al. ${ }^{21}$ meneliti aktivitas antibakteri dari $\mathrm{E} / \mathrm{S}$ dua jenis nekrofagus (Calliphora vicinia Robineau-Desvoidy dan Dermestes maculatus DeGeer) dan detritivore (Tenebrio molitor Linnaeus) dibandingkan dengan $L$. sericata Meigen (kapasitas antibakteri dari E/S telah diketahui) berdasarkan waktu yang diperlukan untuk membunuh lima spesies kuman, yaitu: Staphylococcus aureus, Escherichia coli, Bacillus cereus, Pseudomonas aeruginosa, dan Proteus mirabilis. Aktivitas antibakteri yang diperoleh ialah: $T$. molitor L. dan $D$. maculatus DeGeer yang paling efektif mengontrol pertumbuhan $P$. mirabilis sedangkan blowfly (nekrofagus) lebih efektif mengontrol spektrum yang lebih luas dari bakteri Gram positif dan negatif. E/S larva dari semua spesies ini terbukti dapat mereduksi pertumbuhan kuman dengan perbedaan spektrum bakteri dan derajat potensi antara 4 spesies tanpa lagphase. Hal ini mungkin disebabkan pengaruh ekologi dari waktu kolonisasi setiap serangga pada bangkai. Perbedaan potensi antibakteri dan spektrum dari blowfly dan detritivore dapat diterangkan melalui ekologi bahwa blowfly diperhadapkan dengan berbagai habitat dengan potensi bakteri berspektrum yang lebih luas. Sebagai serangga yang datang pertama, blowfly diperhadapkan bakteri yang berasal dari tubuh mayat/bangkai. Setelah dekomposisi berlangsung, produk gas menggembungkan tubuh dan akhirnya kulit pecah sehingga bakteri dalam usus juga terikut keluar Bakteri obligat anaerob akan mati tetapi yang fakultatif anaerob seperti Proteus spp. dan E. coli dapat bertahan. Detritivore yang datang lebih belakangan diperhadapkan dengan bakteria yang telah berkurang dari tubuh mayat/bangkai, dan mungkin didominasi oleh bakteria yang berasal lingkungan. $P$ mirabilis dalam studi ini mungkin berhadapan dengan E/S detritivore dan bukan E/S blowfly.

Studi sebelumnya mengasumsikan bahwa $\mathrm{pH}$ dari E/S serangga memengaruhi aktivitas antibakteri. E/S dari L. sericata
Meigen dan C. Vicinia bersifat alkalis ( $\mathrm{pH}$ 8-9) sedangkan dari D. Maculatus dan T. Molitor bersifat asam (pH 5-6). Tampaknya efetivitas E/S lebih dipengaruhi oleh jenis bakteri dan bukan oleh $\mathrm{pH}$ karena dengan perubahan $\mathrm{pH}$ efek antibakteri tetap berlangsung. ${ }^{21}$

Infeksi jamur sangat berperan dalam hal morbiditas dan mortalitas pada pasien dengan luka bakar. Sekitar 30\% kasus luka bakar yang tidak menyembuh disertai infeksi jamur. Dermatomikosis merupakan infeksi jamur yang tersebar di seluruh dunia, terutama di daerah tropis dan subtropis. Infeksi ini sulit dikendalikan dan menelan biaya tinggi. Pemakaian jangka panjang obat antifungal memicu resistensi jamur, serta toksistas dan interaksi obat. Diduga lapisan kutikel dari larva mengandung senyawa antifungal dimana asam lemaknya menghambat pertumbuhan hipa dan germinasi spora dari jamur entomopatogenik. Denikian pula senyawa alkohol pada lemak kuktikula larva dan Musca domestica dewasa memperlihatkan efek antifungal tertentu. ${ }^{16}$ Jarczyk et al. ${ }^{13}$ melaporkan eliminasi Candida spp. dari ukus kronis pada kaki setelah pemberian terapi larva. Kemampuan larva menelan jamur dimungkinkan oleh digesti ekstrakorpora. Campuran enzim pencernaan (triptase, peptidase, dan lipase) yang diproduksi terus menerus oleh kelenjar saliva larva ke sekitarnya dapat menyebabkan destruksi dan lisis miselium jamur, kemudian diabsorpsi oleh larva. Kemampuan ingesti larva ialah sebanyak setengah dari berat badannya dalam beberapa menit saja. ${ }^{13}$ Margolin dan Gialanella $^{22}$ meneliti efek antimikroba dari larva in vitro dan melaporkan terjadi lisis lengkap dari kultur MRSA, P. Aeruginosa, vancomycin-resistant Enterococcus dan Candida albicans setelah aplikasi larva 24 jam yang diperlihatkan dengan pengecatan Gram. Alnaimat et al. ${ }^{16}$ meneliti efek larva L. Sericata terhadap jamur infeksi superfisial in vitro dan mendapatkan E/S larva berefek antifungal sedang dan dapat menekan pertumbuhan Trichophyton terrestree. 


\section{Simpulan}

Luka kronis masih merupakan masalah kesehatan di seluruh dunia dengan biaya perawatan yang cukup tinggi. Adanya biofilm mikrobial serta kompleksitasnya pada luka kronis telah disepakati sebagai salah satu kunci gagalnya penyembuhan luka. Biofilm ini memiliki toleransi tinggi terhadap pertahanan pejamu (host), antibiotik, dan antiseptik.

Dengan terjadinya resistensi antibiotik dari berbagai jenis spesies bakteri maka diperlukan terapi alternatif yang cukup efisien dan ekonomis. Terapi larva telah diterima oleh FDA dan telah terbukti berefek antimikroba disamping efek lainnya terhadap penyembuhan luka seperti debrideman mekanis, anti-inflamasi, angiogenesis, dan destabilisasi enzim biofilm pada luka.

Pengembangan AMPs dalam ekskreta/ sekret (E/S) larva terutama defensin yang telah terbukti berkhasiat antimikroba untuk menjadi obat paten masih harus menghadapi tantangan efek samping, toksisitas, efektivitas yang suboptimal, kepekaan terhadap garam, ketahanan terhadap serum protease, serta terjaminnya sistem produksi yang ekonomis dan layak. Studi lanjut diperlukan untuk mengeksplorasi efek terapi larva terutama komponen E/S larva terhadap penyembuhan luka agar dapat diaplikasikan secara lebih estetik.

\section{DAFTAR PUSTAKA}

1. Cowan LJ, Stechmiller JK, Phillips P, Yang QP, Schultz G. Chronic wounds, biofilms and use of medicinal larvae. Ulcers. 2013;2013:1-7. Article ID 487024.

2. James GA, Swogger E, Wolcott R, deLancey Pulcini E, Secor P, Sestrich $\mathbf{J}$, et al. Biofilms in chronic wounds. Woound Rep Reg. 2008;16:37-44.

3. Costerton JW, Stewart PS, Greenberg EP. Bacterial biofilms: a common cause of persistent infections. Microbes, immunity, and disease. Science. 1999;284:1318-22.

4. Bjarnsholt T. The role of bacterial biofilms in chronic infections. APMIS. 2013;121(Supl 136):1-54.
5. Bohova J, Majtan J, Majtan V, Takac P. Selective antibiofilm effects of Lucilia sericata larvae secretions/excretions against wound pathogens. Hindawi Evidence-based Complementary and Alternative Medicine. 2014;2014. Article ID 857360, 9 pages. Available from:

http://dx.doi.org/10.1155/2014/857360.

6. Alhede Maria, Alhede Morten. The biofilm challange. EWMA Journal. 2014;14(1):54-7.

7. Cazander G, Pritchard DI, Nigam Y, Jung W, Nibbering PH. Prospects \& overviews. Multiple actions of Lucilia Sericata larvae in hard-to-heal wounds. Bioessays. 35:0000-0000, 2013 Wiley Periodicals, Inc. DOI 10.1001/bies.201300071.

8. Eming SA, Krieg T, Davidson JM. Inflammation in wound repair: Molecular and cellular mechanisms. Journal of Investigative Dermatology. 2007; 127:514-25.

9. Guo S, DiPietro LA. Factors affecting woound healing. J Dent Res. 2010;89(3):219-29.

10. Bordi C, de Bentzmann S. Hacking into bacterial biofilms: a new therapeutic challenge. Annals of Intensive Care. 2011;1(19):1-8.

11. Wolcott RD, Rhoads DD. A study of biofilm-based wound management in subjects with critical limb ischemia. J Wound Care. 2008;17(4):145-54.

12. Alhede M, Kragh KN, Qvortrup K, Allensen-Holm M, van Gennip $M$, Christensen LD, et al. Phenotypes of non-attached Pseudomonas aeruginosa aggregates resemble surface attached biofilm. PloS One. 2011;6:e27943.

13. Jaklic D, Lapanje A, Zupancic K, Smrke D, Gunde-Cimerman N. Selective antimicrobial activity of maggots against pathogenic bacteria. Journal of Medical Microbiology. 2008;57:61725.

14. Andersen AS, Sandvang D, Schnorr KM, Kruse T, Neve $S$, Joergensen $B$, et al. A novel approach to the antimicrobial activity of maggot debridement therapy. J Antimicrob Chemother. 2010;65:1646-54.

15. Cerovsky V, Bem R. Lucifensins, the insect defensins of biomedical 
importance: The story behind maggot therapy. Pharmaceuticals. 2014;7:25164.

16. Alnaimat S, Wainwright $M$, Aladaileh SH. An initial in vitro investigation into the potential therapeutic use of Lucilia sericata maggot to control superficial fungal infections. JJBS. 2013;6(2):13742.

17. Chan DCW, Fong DHF, Leung JYY, Patil NG, Leung GKK. Maggot debriedment therapy in chronic wound care. Hong Kong Med J. 2007;13(5):382-6.

18. Singh NM, Bhatia SK, Singh G. Maggots therapy in facilitating wound debridement: Present status. Medical Journal of Dr. D. Y. Patil University. 2004;7(5):639-42.

19. Courtenay M, Church JCT, Ryan TJ. Larva therapy in wound management.
Journal of the Royal Society of Medicine. 2000;93:72-4.

20. Hinshaw J. Larval therapy: A review of clinical human and veterinary studies. World Wide Wounds. October 2000. [cited 2014 Nov 10]. Available from: http://www.worldwidewounds.com/200 0/oct/Janet-Hinshaw/Larval-TherapyHuman-and-Veterinary.html.

21. Barnes KM, Gennard DE, Dixon RA. An assessment of the antibacterial activity in larval excretion/secretion of four species of insects recorded in association with corpses, using Lucilia sericata Meigen as the marker species. Bulletin of Entomological Research. Doi: 10.1017/S000748530999071X，6 pages.

22. Margolin L, Gialanella P. Assesment of the antimicrobial properties og maggots. Int Wound J. 2010;7:2002-4. 